\title{
EXPLORING ELEMENTS OF INFORMALITY IN TEAMS IN PETROLEUM INDUSTRY
}

\section{DEBASISH MUKHERJEE \& DR NITIN ARORA}

Research Scholar, AIBS, Amity University, Noida, India

Professor, AIBS, Amity University, Noida, India

\begin{abstract}
Various factors impact the effectiveness of teams. Literature on Teams lists a number of such factors. This Research Paper identifies a new factor 'Informality', which is a measure of the formal hierarchical structure among members of a multi-disciplinary team. Qualitative research on this Formality identifies some interesting features of the correlation of this 'Informality' with Team Effectiveness, in the context of teams in the information-intensive Indian upstream Petroleum Industry. The research methodology was primary data from senior team leads in public sector petroleum exploration companies Oil and Natural Gas Corporation Limited (ONGC). The findings show that Informality depends on factors which can be clubbed under two main classes: Communication Pattern and Age Difference among Team members. The findings reveal that even in semi-formal teams, these two dimensions make the teams effective in two diverse aspects.
\end{abstract}

KEYWORDS: Petroleum Industry, Informality

Received: Jun 10, 2020; Accepted: Jun 30, 2020; Published: Jul 21, 2020; Paper Id.: IJMPERDJUN2020409

\section{INTRODUCTION}

Drivers of team and group effectiveness have been receiving research attention for quite some time [1]. A number of theories [2] have been used to analyse and correlate the variation in team performance with various team-related features. Such theories can be divided into two categories: (i) Compositional theories which draw from the individual characteristics of the team members and (ii) Structural theories which focus on the interaction chemistry among those members. Various constructs have been used [3] to understand and measure [4] team behaviour. It has been seen [12] that interaction (structure-related) chemistry can improve performance of the same team composition significantly. One of the main determinants of team structure has been the level of 'Informality' in a Team. In the information-intensive Upstream Petroleum Industry (exploration and production of crude oil and natural gas), this 'Informality' is yet to be receive significant scholarly attention. This paper adopts an operational measure of 'Informality' - the number of team members who are known by their nicknames by the other members. This paper probes the elements of 'Informality' of teams and develops a theory around it, in the upstream petroleum industry.

\section{LITERATURE REVIEW}

A study on team Structure by J. R. Hollenbeck, and M. Spitzmuller, "Team Structure: Tight Versus Loose Coupling in Task-Oriented Groups," The Oxford Handbook of Organizational Psychology, vol. 2, 2012 [7]lists the virtues and liabilities of each of the four types of interdependence in teams, and finds that loose coupling may be a normative, and not just a descriptive, practice of organizational teams. 
S. W. J. Kozlowski, B. S. Bell [11] provides an integrative perspective on work groups and teams in organizations, one that addresses primary foci of theory and research, highlights applied implications, and identifies key issues in need of research attention and resolution.

A recent study on Team Classification [14] identifies two variables for classifying Teams in Upstream Petroleum Industry: Degree of Interdependence (Collaboration) and Information Diversity. Any team in the Upstream Petroleum Industry can be classified in this conceptual grid by analysing these two constructs. To find out the grid position (coordinates) of any specific team, we need to find out the composition of the team members which drive their information residency pattern. The grid position of any team has important clues to its performance measures.

'Informality and Teamwork' [9]finds that meetings of teams are more focused on tasks in formal set-ups, whereas informal set-ups result in more general discussions at the beginning and at the end.

'Informal Groups in Global Work Environment: Group Work or Team Work?'[16] postulates that informal structures function on the ground of formal ones either to compensate some of the shortcomings of formal groups or to complete them or simply to neutralise their rigidity. There are also situations when informal structures within a group, although initially presented as such, tend to formalize themselves along the way to confer some degree of efficiency to the group. Evolution of a group to the team stage takes time; team represents a superior stage in group development. Therefore, teams will hold both the advantages of formal group (efficiency, rigorous organization, normative system, common to all members) and also those of the informal group (open communication, flexibility, adaptability).

In the classic research in 'Groups: Interaction and Performance,' McGrath [12] analyses the micro interaction process in groups. The communication modalities in groups are termed as Communication Pattern which when juxtaposed with the relationship pattern to have effective impacts on group performance. This seminal work also throws light on Group Development, i.e. how the relationship among group members changes over a period of time.

A G. Woodside (19) finds that people relate to each other in terms of stories. There is evidence in literature that substantive information is stored, indexed and retrieved in the form of stories. Drawing from that, we evolve another construct 'Story-telling' (ST). We define this 'Story-telling' is the average number of personal stories each Team Member knows of the other members. Stories about their homes, their personal lives, their children, other friends. This is a significant factor in team bonding.

J. Z. Paul, "The Neuroscience of Trust," Harvard Business Review (January 2017 issue), 2016[15] finds that Trust in organizations and teams can be managed with approaches like 'Recognizing Excellence', 'Inducing Challenges', 'Giving members discretion how they work' and 'Sharing Information'.

\section{METHODOLOGY}

An exploratory methodology has been followed for this paper. Primary Data were collected from 11Team leads of Drilling and Exploration teams in Upstream Petroleum company Oil and Natural Gas Corporation Limited (ONGC,

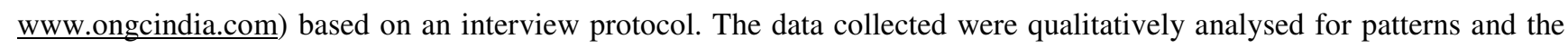
findings reported below. 


\section{FINDINGS}

The transcripts of the discussions with various team leads in public enterprise Oil and Natural Gas Corporation Limited (ONGC) is tabled below:

Table 1

\begin{tabular}{|c|c|c|c|}
\hline S. No & Name, Designation & $\begin{array}{l}\text { Experience } \\
\text { (years) as } \\
\text { Team Lead }\end{array}$ & Views \\
\hline 1 & $\begin{array}{l}\text { Sanjeev Sharma, } \\
\text { General Manager }\end{array}$ & 36 & $\begin{array}{l}\text { Informality can be measured by the number of casual meetings } \\
\text { (without any specific agenda) the members of the team have, } \\
\text { especially in Exploration teams for better intellectual } \\
\text { brainstorming. These meetings are basically socializations or } \\
\text { spending a good time, as a break or relief from official chores. } \\
\text { The more open and unstructured the Communication, more } \\
\text { informal the team is in its relationship.Apart from that, if the } \\
\text { team members are like friends, informality is more in that team. } \\
\text { Moreover, if the average age is higher, the team can perform } \\
\text { strategic tasks as well like Investment decisions for new oil } \\
\text { fields. }\end{array}$ \\
\hline 3 & Harish Awal & 35 & $\begin{array}{l}\text { Story Telling approach in conversations is a very strong indicator } \\
\text { of Informality in Teams. Story telling can take place when the } \\
\text { predominant pattern of communication is casual. Structure brings } \\
\text { in formality in a team. Such Formal structure helps in Board } \\
\text { meetings for high-level policy decisions which have long-term } \\
\text { impact on organizations. }\end{array}$ \\
\hline 2 & $\begin{array}{l}\text { Amrinder Singh, } \\
\text { General Manager }\end{array}$ & 34 & $\begin{array}{l}\text { In Operational Teams like Drilling and production teams, } \\
\text { meetings are blunt viz. criticism is direct and clear even against } \\
\text { the team lead (during operations team lead's decision is final), no } \\
\text { hidden grievances, all members participate. Nobody other than } \\
\text { team members participate in team meetings. There is no } \\
\text { predetermined structure in the communication approach. }\end{array}$ \\
\hline 4 & Tanuj Upadhyay & 33 & $\begin{array}{l}\text { A close-knit, friendly group with unstructured communication is } \\
\text { a classic example of informal team. If the team comprises of } \\
\text { senior people, it can be a high-level strategic group. For } \\
\text { operational jobs like Drilling and Exploration teams, a younger } \\
\text { group is better. }\end{array}$ \\
\hline 5 & $\begin{array}{l}\text { Sanjay Joshi, } \\
\text { General Manager }\end{array}$ & 27 & $\begin{array}{l}\text { The number of members of the team who call themselves by their } \\
\text { nicknames can be a good measure of Informality of the team. If } \\
\text { the age difference between team members is less, the team is } \\
\text { informal. However, in top management teams, too casual } \\
\text { approach may be counter-productive in some cases. But } \\
\text { 'Formality' is good for Board level teams where important } \\
\text { decisions are needed and diverse viewpoints are is required. }\end{array}$ \\
\hline 6 & Vivek Mehrotra & 25 & $\begin{array}{l}\text { The Number of occasions where team members share tiffin/lunch } \\
\text { during office time is a good measure of Informality in the team. } \\
\text { Such closeness occurs when the age brackets of team members } \\
\text { are not very different. Communication in such scenarios are } \\
\text { unstructured. In some teams on fields, unstructured } \\
\text { communication is needed but the age difference may be higher as } \\
\text { different skill sets are needed. }\end{array}$ \\
\hline 7 & L L Gohare & 22 & $\begin{array}{l}\text { If average age is low, the team is better for operational tasks and } \\
\text { if the average age is high, the team is better suited for strategic } \\
\text { decision-making }\end{array}$ \\
\hline
\end{tabular}




\begin{tabular}{|c|l|c|l|}
\hline 8 & $\begin{array}{l}\text { Sujeet Sairam, } \\
\text { Senior CC officer }\end{array}$ & 12 & $\begin{array}{l}\text { The pattern of communication is vital in measuring the } \\
\text { informality of a team. The number of occasions when feedback } \\
\text { on performance is given by members and received gracefully by } \\
\text { the member (s) concerned. Especially in cases where the team } \\
\text { goal depends on gradual improvement, feedback is vital for } \\
\text { improving performance. }\end{array}$ \\
\hline 9 & Abhinav Khanna & 5 & $\begin{array}{l}\text { If families of team members are also known to each other, it may } \\
\text { improve informality. Hence, the number of members who know } \\
\text { families, can be a measure of Informality of the team. Indirectly, } \\
\text { this happens when the team members are roughly of the same age } \\
\text { groups. If the age difference among members is high, formality } \\
\text { creeps in. }\end{array}$ \\
\hline 10 & Shrey Ratan & 5 & $\begin{array}{l}\text { The communications which take place between the team } \\
\text { members, are more in whatsapp and calls than formal } \\
\text { communication channels like e mail. }\end{array}$ \\
\hline 11 & Bagmishree & 5 & $\begin{array}{l}\text { Hierarchies are very rarely referred in structured exchanges in } \\
\text { informal teams. So, the age profile of members need to be similar } \\
\text { if hierarchy is not a factor at play. That makes teams informal. }\end{array}$ \\
\hline
\end{tabular}

\section{METHODOLOGY}

\section{Analysis of Findings}

A content analysis has been carried out on the responses. The following pattern emerges from the analysis. The key variables identified can be the measurement index for Informality of a team. The main variables (and the broad group to which these belong) which come out are:

Table 2

\begin{tabular}{|c|l|}
\hline Serial & \multicolumn{1}{c|}{ Key Variable } \\
\hline 1 & Nicknaming \\
\hline 2 & Out-of-office-socializations \\
\hline 3 & Feedback given freely, without hierarchy \\
\hline 4 & Sharing Tiffins/Lunches \\
\hline 5 & Families known to each other \\
\hline 6 & Criticism is direct \\
\hline 7 & Hierarchy reference in exchanges \\
\hline 8 & Number of causal meetings without agenda \\
\hline 9 & Story telling \\
\hline
\end{tabular}

Based on the above key variables which emerged from the findings, we can carry out a sort of Factor Analysis. It is observed that each one of the above nine variables into two broad classes of variables, to focus on the key dimensions behind Informality in a team.

We can combine (1) Nicknaming, (2) Out of Office socializations, (4) Sharing Tiffins/Lunches, (5) Families Known to each other and (7) Hierarchy reference in exchanges into one variable class which we can name as 'Age Difference among Team members'. This is because these five variables are true normally when the age difference among team members are less, i.e. most members are of the same age.

Again, we can combine (3) Feedback given freely, without hierarchy, (6) Criticism is direct and (8) Number of casual meetings without agenda and (9) Story-telling, into another variable class which we can name as 'Communication 
Pattern'. This is because all these four variables relate to Open Communication which correlates with Informality in the teams.

Based on the above Factor groupings, we can tabulate the nine variables and the two broad categories which thus become the key determinants behind operationalizing Informality in teams in petroleum industry. We also indicate the findings corresponding to each variable, juxtaposing (moderated) with the impact of the other variable vis-a-vis the Informality or Formality in the Teams.

Table 3

\begin{tabular}{|c|c|c|c|}
\hline Serial & Variable & Broad Group & Findings \\
\hline 1 & Nicknaming & $\begin{array}{l}\text { Age Difference } \\
\text { among Team } \\
\text { members }\end{array}$ & $\begin{array}{l}\text { Low age difference makes teams informal, provided the } \\
\text { Communication pattern in Open. If Communication Pattern is } \\
\text { structured and Age difference is low, it is semi-formal and the } \\
\text { team is poised for strategic tasks like Investments decisions. }\end{array}$ \\
\hline 2 & $\begin{array}{l}\text { Out-of-office- } \\
\text { socializations }\end{array}$ & $\begin{array}{l}\text { Age Difference } \\
\text { among Team } \\
\text { members }\end{array}$ & $\begin{array}{l}\text { Low Age difference operationalizes such Out-of-office- } \\
\text { Socializations, which reflect tightly-coupled structures. }\end{array}$ \\
\hline 3 & $\begin{array}{l}\text { Feedback given } \\
\text { freely, without } \\
\text { hierarchy }\end{array}$ & $\begin{array}{l}\text { Communication } \\
\text { Pattern }\end{array}$ & $\begin{array}{l}\text { Unstructured Communication imparts Informality to teams. } \\
\text { Feedback makes a structure tightly coupled. }\end{array}$ \\
\hline 4 & $\begin{array}{l}\text { Sharing } \\
\text { Tiffins/Lunches }\end{array}$ & $\begin{array}{l}\text { Age Difference } \\
\text { among Team } \\
\text { members }\end{array}$ & $\begin{array}{l}\text { Younger group share lunches and tiffins together which improves } \\
\text { bonding and makes interactions informal. }\end{array}$ \\
\hline 5 & $\begin{array}{l}\text { Families } \\
\text { known to each } \\
\text { other }\end{array}$ & $\begin{array}{l}\text { Age Difference } \\
\text { among Team } \\
\text { members }\end{array}$ & Close family bond improves relationships ate work \\
\hline 6 & $\begin{array}{l}\text { Criticism is } \\
\text { direct }\end{array}$ & $\begin{array}{l}\text { Communication } \\
\text { Pattern }\end{array}$ & $\begin{array}{l}\text { Direct feedback and criticism makes teams informal and is good } \\
\text { for intellectual work for finding out solutions. If communication } \\
\text { pattern is structured, important organizational decisions can be } \\
\text { worked out by the team but will be time-consuming. }\end{array}$ \\
\hline 7 & $\begin{array}{l}\text { Hierarchy } \\
\text { reference in } \\
\text { exchanges }\end{array}$ & $\begin{array}{l}\text { Age Difference } \\
\text { among Team } \\
\text { members }\end{array}$ & $\begin{array}{l}\text { Hierarchy features in exchanges in formal settings which are } \\
\text { needed for Board level work, when various types of inputs are } \\
\text { required for long-term policy-type decisions. }\end{array}$ \\
\hline 8 & $\begin{array}{l}\text { Number of } \\
\text { casual meetings } \\
\text { without agenda }\end{array}$ & $\begin{array}{l}\text { Communication } \\
\text { Pattern }\end{array}$ & $\begin{array}{l}\text { Such unstructured communication can either make the team } \\
\text { informal if the Age difference is low. Otherwise, with high age } \\
\text { difference, semi-formal team set ups emerge which are good for } \\
\text { Operational assignments. On the other hand, low Age Difference } \\
\text { and Structured Communication Pattern gives rise to another type } \\
\text { of semi-formal team set up which are beneficial for strategic } \\
\text { assignments. }\end{array}$ \\
\hline 9 & Story telling & $\begin{array}{l}\text { Communication } \\
\text { Pattern }\end{array}$ & $\begin{array}{l}\text { Unstructured communication pattern leads to Informal set up } \\
\text { when the Age Difference is low. }\end{array}$ \\
\hline
\end{tabular}

\section{PROPOSITIONS}

Based on the above analysis and findings, we can develop a theoretical proposition through the following matrix. The proposed matrix shows the results of the operationalized interplay of 'Age Difference among Team members' and 'Communication Pattern'. The types of team assignments [Operational, Intellectual, Strategic] which benefit from such Informal, Semi-formal and Formal teams are also brought out in the matrix below. 


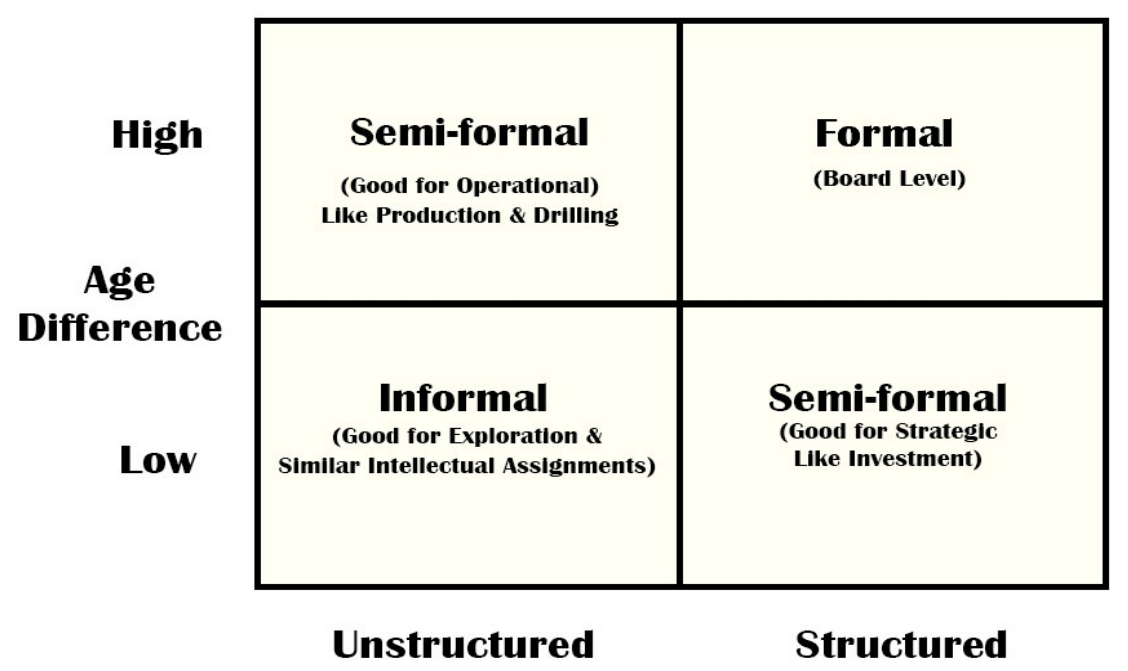

\section{Communication Pattern}

Figure 1

\section{DIRECTIONS FOR FURTHER RESEARCH}

The study is based on a judgemental sample of team leads in the upstream petroleum company Oil and Natural Gas Corporation Limited (ONGC). A bigger sample including team leads of other public sector enterprises in petroleum industry (like Oil India Limited) would give more insights into the fine-grained nuances of the subject, and some other classes of operational dimensions may emerge.

\section{REFERENCES}

1. H. Arrow, J. E. McGrath, and J. L. Berdahl, "The Study of Groups: Past, Present, and Future," Personality and Social Psychology Review, vol. 4(1), pp. 95-105,2000

2. V. Dolen V, De Ruyter, and J. Carman, "The role of self-and group-efficacy in moderate group chat," Journal of Economic Psychology, vol. 27, pp. 324-343, 2006

3. R. A. Guzzo, P. R. Yost, R. J. Campbell, and G, P. Shea, "Potency in groups: Articulating a construct," British Journal of Social Psychology, vol. 32(1), pp. 87-106, 1993

4. D. J. Hand, "Measurement: A very short introduction," Oxford: Oxford University Press, 2016

5. A. M. Hardin, M. A. Fuller, and R.M. Davison, "I Know I Can, But Can We? Culture and Efficacy Beliefs in Global Virtual Teams," Small Group Research, vol. 38(1), pp. 130-155, 2007

6. V. B. Hinsz, R. S. Tindale, and D. A. Vollrath, "The emerging conceptualization of groups as information processors," Psychological Bulletin, vol. 121(1), pp. 43-64, 1997

7. J. R. Hollenbeck, and M. Spitzmuller, “Team Structure: Tight Versus Loose Coupling in Task-Oriented Groups,” The Oxford Handbook of Organizational Psychology, vol. 2, 2012 
8. D. R. Ilgen, J. R. Hollenbeck, M. Johnson, and D. Jundt, “Teams in Organizations: From Input-Process-Output Models to IMOI Models," Annual Review of Psychology, vol. 56, pp. 517-543, 2005

9. B. Kane, P. J. Toussaint, and K. O'Bryne, “Informality and Teamwork,” 2013

10. D. Katz D, and R. L. Kahn, "The social psychology of organizations," 1978

11. S. W. J. Kozlowski, B. S. Bell, "Work Groups and Teams in Organizations," 2003

12. J. E. McGrath, "Groups: Interaction and Performance," 1984

13. M. Mortensen, and H. K. Gardner, "The Overcommitted Organization,” Harvard Business Review, September October 2017

14. D. Mukherjee, N. Arora, and S. Kapoor, “Team Classification in Upstream Petroleum Industry,” 2017

15. J. Z. Paul, "The Neuroscience of Trust," Harvard Business Review (January 2017 issue), 2016

16. Z. Raluca, and V. Romulus, “Informal Groups in Global Work Environment: Group Work or Team Work?” 2015

17. JW Whiteoak, L Chalip, L K Hort, “Assessing Group Efficacy: Comparing Three Methods of Measurement,” Small Group Research, vol. 35(2), pp. 158-173, 2004

18. B. M. Wright, J. R. Barker, J. L. Cordery, and B. E. Maue, "The ideal participative state: A prelude to work group effectiveness," Journal of Business and Management, vol. 9, pp. 171-188, 2003

19. A G. Woodside (2016) - Case Study Research: Core Skill Sets in Using 15 Genres [pp 41-83], Emerald Group Publishing Limited

20. Rajesh, S., B. M. Kulkarni, and S. Shanmukhappa. "Investigations on fuel properties of ternary mixture of ethanol, bio diesel from acid oil and petroleum diesel to evaluate alternate fuel for diesel engine." International Journal of Research in Engineering and Technology, 2 (6), 181188 (2014).

21. Aghedr, Mustafa Mohamed, and Yavuz Demirel. "THE IMPORTANCE OF FINANCIAL DECISIONS IN PETROLEUM FIRMS." IMPACT : International Journal of Research in Business Management(IMPACT : IJRBM) (2019): 9-16

22. Gabriel, Amakievi Okien Ijoma, and Sarah Ebenezer Blackduke. "LIFELONG AND LIFEWIDE EDUCATION IN TWENTY FIRST CENTURY NIGERIA: CONTRIBUTIONS OF ELF PETROLEUM NIGERIA LIMITED FROM 2005-2016." International Journal of Humanities and Social Sciences(IJHSS) (2019): 9-26

23. Kalita, M., and A. Devi. "Study on the effects of soil ph and addition of npk fertilizer on degradation of petroleum hydrocarbon present in oil-contaminated soil." International Journal of Chemical and Petrochemical Technology (IJCPT) 2.3 (2012): 9-22. 
